\title{
Experimental Investigation on Microstructure and Mechanical Properties of Direct Squeeze Cast Al-13\%Si Alloy
}

\author{
S. Souissi, ${ }^{1}$ M. Ben Amar, and C. Bradai \\ National Engineering School of Sfax, Tunisia \\ ${ }^{1}$ slim.souissi@ymail.com
}

УДК 539.4

\section{Экспериментальное исследование микроструктуры и механических свойств сплава $\mathrm{Al}-13 \% \mathrm{Si}$, полученного литьем под давлением}

\author{
С. Свисси, М. Бен Амар, Ч. Брадаи
}

Национальный инженерный институт г. Сфакс, Тунис

\begin{abstract}
Для литья под давлением характерно приложение давления к заготовке при ее затвердевании, вследствие чего активизируются различные физические проиессы, которые влияют на металлургические свойства литых сплавов. Выполненное экспериментальное исследование свидетельствует о влиянии уровня давления на микроструктуру и механические характеристики сплава Al-13\% Si. Показано, что давление при литье в интервале 0,1..100 МПа приводит к уменьшению зерен, улучшению прочностных свойств и повышению твердости по Виккерсу в центральной части образцов. При давлении 100..150 МПа наблюдаются высокие предварительные деформации при высокой температуре литья и укрупнение зерен, в результате чего ухудшаются прочностные свойства и уменьшается твердость. Анализ микрофотографий на электронном микроскопе показывает, что при давлении до 100 МПа механизм разрушения является более вязким, чем при повышенном давлении. Это позволяет оптимизировать уровень давления с иелью предотвращения ухудшения свойств и ликваџии материала в проиессе литья под давлением.
\end{abstract}

Ключевые слова: литье под давлением, оптимизация, сплав $\mathrm{Al}-13 \% \mathrm{Si}$, микроструктура, механические свойства.

Introduction. The increasing demand for weight reduction in the automotive industry has had a considerable effect on the selection of light materials $[1,2]$. For this reason, the Al-Si alloys are more and more used by the most important industrial aluminium foundry. They provide a number of merits, such as good castability, high mechanical properties, excellent wear resistance, high thermal conductivity, high specific rigidity and attractive tensile strength [3-11].Over the years, there have been remarkable efforts to minimize casting defects and improve service life of as-cast products by implementing new casting routes. However, in order to minimize the negative effects caused by casting defects, special casting processes, such as low-pressure die-casting and squeeze casting, have been actually employed in the automobile component casting $[12,13]$. Squeeze casting is one of 
the modern casting processes, which have been invented to address these imperfections and has a high potential to produce sound castings. It is a metal forming process which combines permanent mould casting with die forging into a single operation where molten metal is solidified under applied hydrostatic pressure [14]. Part of the advantages of squeeze casting is that it provides near net shape processing with a minimal machining and a good surface of finished components with dimensional accuracy. In recent years, many research works on squeeze casting have been conducted. Several effects of the squeeze casting process parameters on the mechanical properties of casting have been widely studied. Squeeze casting has improved tensile properties, specifically ultimate tensile strength and elongation, for the squeeze cast specimens over the conventional high-pressure die cast parts [15]. The influence of squeeze pressure on macrostructure and microstructure of a number of alloy systems has been reported. Squeeze casting decreased relatively the percentage of porosity in the microstructure and increased the density [16]. In fact, if the pressure of dissolved gas in the melt is higher than the external pressure acting on it, gas bubbles would be nucleated during solidification. Gas porosity is formed when these gas bubbles are trapped in the last solidified interdendritic regions. Therefore, continuous application of pressure throughout the solidification prevents gas porosity. In addition, the shrinkage porosity is created by the introduction of molten metal in the interdendritic regions $[17,18]$. The increase of applied pressure leads to decreasing the grain size and the secondary dendrite arm spacing of the primary $\alpha$-phase, modifying the eutectic silicon particles and improving hardness [19-21].

In this work, an $\mathrm{Al}-13 \% \mathrm{Si}$ alloy manufactured via direct squeeze casting under various pressure levels and gravity die casting is studied. The effect of the applied pressure on the microstructure, the mechanical properties and the fracture behaviours and the correlation between their characteristics are analysed and discussed in order to optimize the most adequate pressure level.

\section{Experimental Procedure.}

1.1. Material. The material used in this study is $\mathrm{Al}-13 \% \mathrm{Si}$ alloy. Chemical properties of the used alloy are presented in Table 1.

$\mathrm{T}$ a b 1 e 1

Chemical Composition (wt.\%) of the Alloy Used in This Work

\begin{tabular}{|c|c|c|c|c|c|c|c|c|}
\hline $\mathrm{Si}$ & $\mathrm{Cu}$ & $\mathrm{Mg}$ & $\mathrm{Fe}$ & $\mathrm{Mn}$ & $\mathrm{Pb}$ & $\mathrm{Zn}$ & $\mathrm{Cr}$ & $\mathrm{Al}$ \\
\hline 13.1 & 0.01 & 0.11 & 0.35 & 0.068 & 0.03 & 0.14 & 0.03 & Rest \\
\hline
\end{tabular}

1.2. Casting Method. The squeeze-casting experiments are performed on the experimental setup presented in Fig. 1.

The pressure on the molten metal is kept constant until the end of solidification. The punch-and-die set is made of hot-die steel and the cast specimens are hexagonal in shape; $8 \mathrm{~mm}$ in side length and $120 \mathrm{~mm}$ in length. The die is preheated up to $250^{\circ} \mathrm{C}$ and the melt is poured through the pouring gate into the die at $750^{\circ} \mathrm{C}$. The manufacturing conditions of prepared specimens are presented in Table 2. 
$\mathrm{T}$ a $\mathrm{b} 1$ e 2

Process Conditions of the Specimens

\begin{tabular}{||c|c|c|}
\hline \hline Pouring temperature $\left({ }^{\circ} \mathrm{C}\right)$ & Die preheating temperature $\left({ }^{\circ} \mathrm{C}\right)$ & Applied pressure $(\mathrm{MPa})$ \\
\hline \multirow{2}{*}{250} & 250 & 0.1 (gravity) \\
& & 50 \\
& & 75 \\
& & 100 \\
& & 150 \\
\hline
\end{tabular}

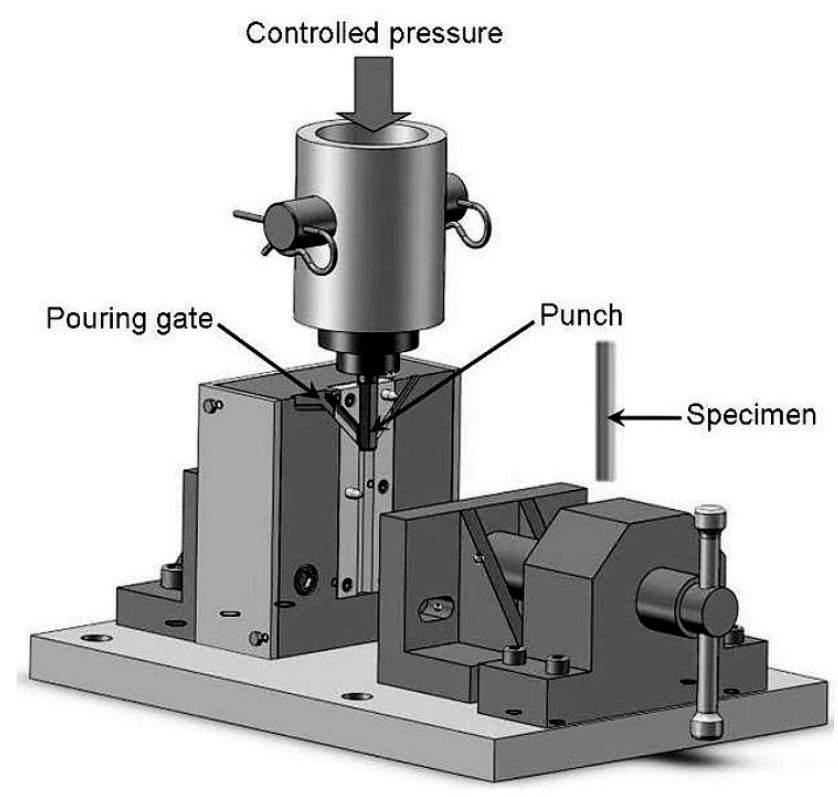

Fig. 1. Experimental setup with steel mould used in the squeeze casting process.

1.3. Microstructural Analysis. In order to investigate the effect of applied pressure on the microstructure, a series of pictures is performed using an optical microscope LEICA DMLP with a digital camera JVC. Each specimen is prepared and etched with Kellers reagent [22]. A fracture tensile specimens study is carried out using a scanning electron microscope JEOL $6460 \mathrm{LV}$ under $20 \mathrm{kV}$.

1.4. Tensile Tests. In order to evaluate mechanical properties of the gravity and squeeze cast specimens, tests are carried out in an Instron-5567 tensile materials testing machine. The tests are performed under displacement control, with a rate of displacement starting at $2 \mathrm{~mm} / \mathrm{min}$. An extensometer (gage length of $12.5 \mathrm{~mm}$, Mod. 2620-601, Instron Corp.) is attached with two rubber bands to the central part of the specimen. For each casting condition four specimens are tested and the mean results are reported. The geometry of the tensile specimens is shown in Fig. 2.

1.5. Hardness Measurement. The hardness of the gravity and squeeze cast specimens is measured by using MEKTON Vickers Hardness Tester and a load of $0.5 \mathrm{~kg}$. Each test is repeated at least five times to get a good average with minimum deviation. Measurements are taken in two different locations in the centre and edge of specimens. 


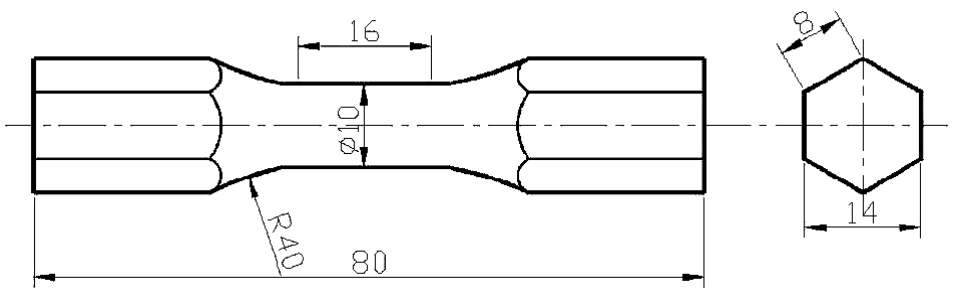

Fig. 2. Geometry of tensile test specimen (in $\mathrm{mm}$ ).

\section{Results and Discussion.}

2.1. Microstructure. It is well known that mechanical properties depend on microstructure. In order to compare the microstructures of the different squeezing pressures used in this study, they are taken from the edge and the middle zone of specimens as shown in Figs. 3 and 4, respectively.
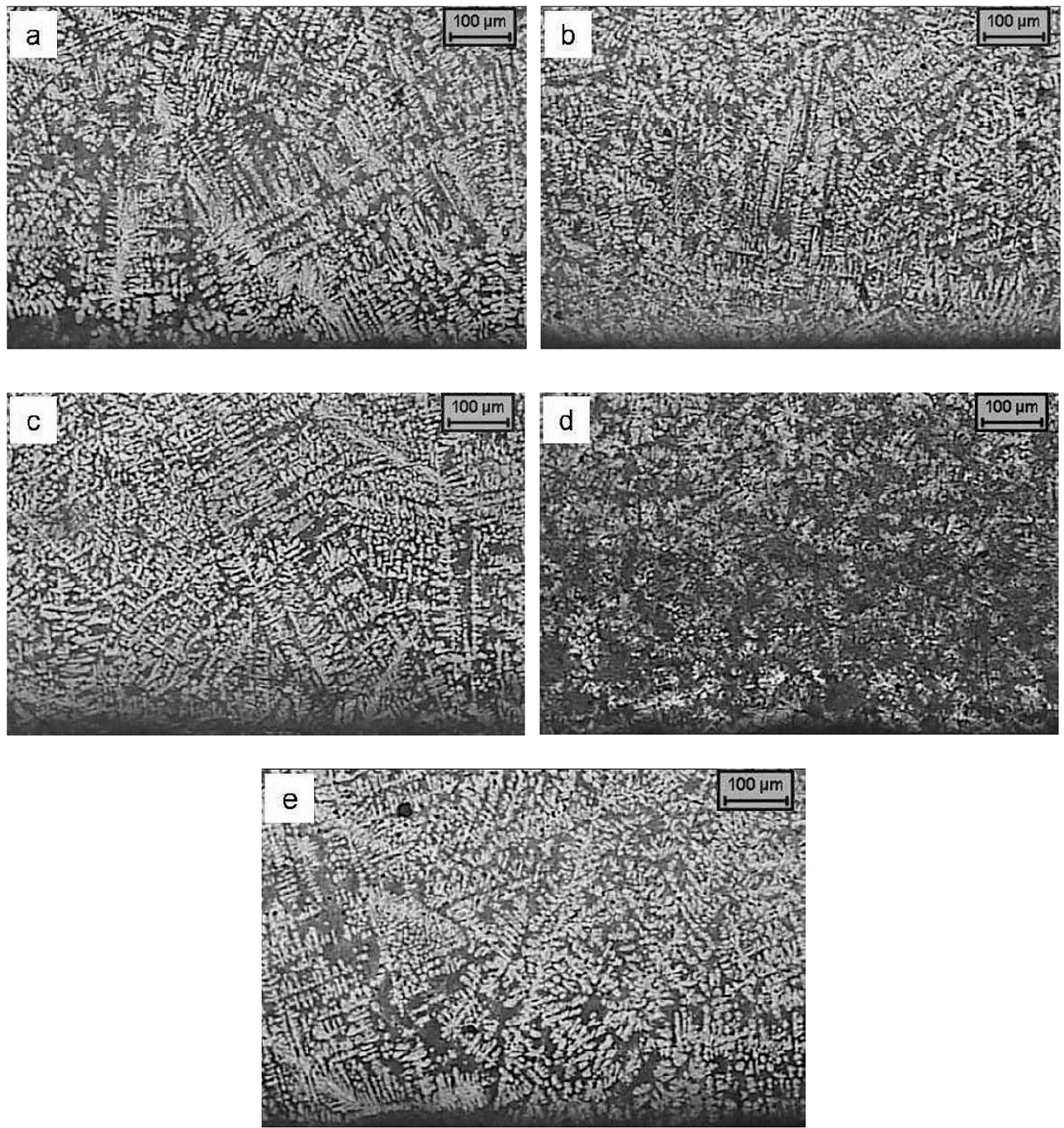

Fig. 3. Optical micrographs of metallographic sections of cast specimens at the edge: (a) $0.1 \mathrm{MPa}$; (b) $50 \mathrm{MPa}$; (c) $75 \mathrm{MPa}$; (d) $100 \mathrm{MPa}$; (e) $150 \mathrm{MPa}$. 

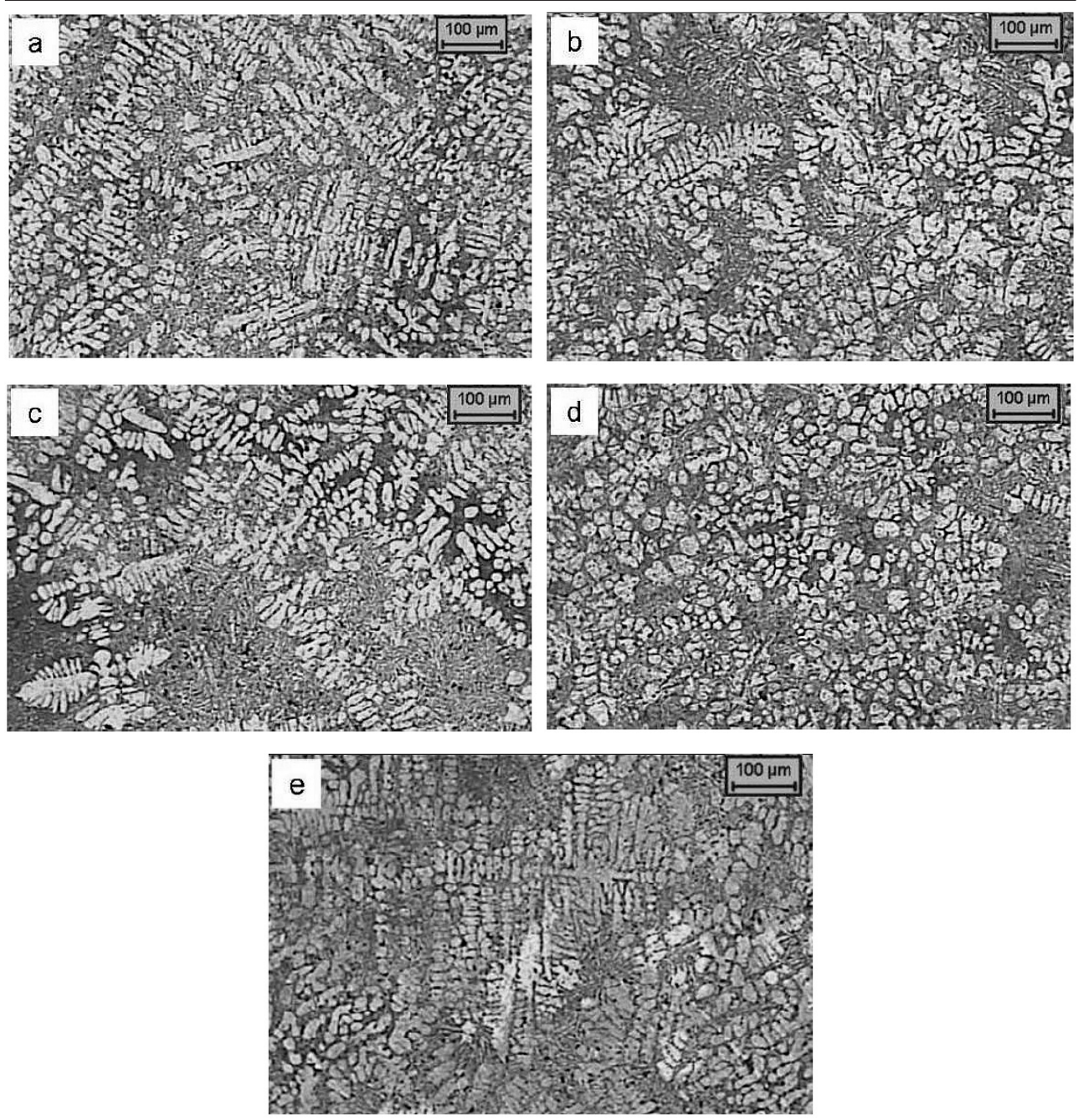

Fig. 4. Optical micrographs of metallographic sections of cast specimens on the middle zone: (a) $0.1 \mathrm{MPa}$; (b) $50 \mathrm{MPa}$; (c) $75 \mathrm{MPa}$; (d) $100 \mathrm{MPa}$; (e) $150 \mathrm{MPa}$.

Figure 3 shows that all specimens have a fine dendritic structure of the $\alpha$-primary phase at the edge. Its noticed that the dendrite size appears to be almost comparable. This refinement in structure is due to the increase in cooling rate which occurs by the higher heat transfer coefficient as a result of the contact between the melt and the die wall. In the middle zone, the comparison between different microstructure aspects for the different applied pressure is provided in Fig. 4. The microstructure of a gravity cast specimen as seen in Fig 4a contains coarse size dendrites. Furthermore, the gravity casting produces highly developed dendrites with a larger DAS because of the long time solidification. Micrographs in Fig. $4 \mathrm{~b}-\mathrm{d}$, show the microstructure of squeeze cast specimens that are produced under 50,75, and $100 \mathrm{MPa}$ pressures, respectively. These micrographs reveal that the microstructures of squeeze cast specimens, which are prepared under higher applied pressures, are much finer. It is clear that the applied pressure has significant influence on the microstructure of the alloy. Moreover, the dendrite size 
of the alloy decreases with the increase of the squeezing pressure. The application of pressure causes greater cooling rates for the solidifying alloy which can be realized due to reduction in the air gap between the alloy and the die wall, hence a larger effective contact area. Obviously, the increase of the undercooling degree and heat-transfer coefficient will result in the refinement of the grain size of squeeze casting alloy $[23,24]$, as a result the specimen structure becomes thinner as shown in Fig $4 b-d$. It is noted that when applied pressure is increased, the DAS is decreased. This effect can be justified by the equation suggested by Ghomashchi and Vikhrov [25]:

$$
P=P_{0} \exp \left(\frac{-\Delta H_{f}}{R T_{f}}\right) .
$$

Increasing pressure $P$ causes an increase in the freezing point $T_{f}$ of the alloy. In this equation, $\Delta H_{f}$ is the latent heat of fusion and $P_{0}$ and $R$ are constants. Increasing the freezing point brings about undercooling in an initially superheated alloy and consequently increases nucleation frequency, causing a finer grain size structure. On a mechanistic approach, such change in freezing temperature is expected due to the reduction in interatomic distance with increasing pressure and thus restriction of atomic movement, which is the prerequisite for melting/ freezing. The inter-solubility of constituent elements together with the solubility of impurity and trace elements is also expected to increase with pressure [25]. Figure 4e shows the microstructure of the squeeze cast specimen under $150 \mathrm{MPa}$ pressure. The results show that the dendrite size of the alloy increases. They are more developed than that under 50, 75, and $100 \mathrm{MPa}$ squeezing pressure. This could be due to a severe deformation after solidification in elevated temperature. In fact, the presence of the temperature during the severe plastic deformation can cause coarsening of the particles of silicon and aluminum grain growth.

2.2. Tensile Properties. Figure 5 exhibits the effects of applied pressure on the typical tensile properties of cast specimens. The gravity cast specimens has the lowest tensile properties. The increase of the ultimate tensile strength (UTS) and the yield strength $\left(Y S_{0.2}\right)$ with applied pressure up to $100 \mathrm{MPa}$ shows a good synchronized effect with increasing of elongation. More specifically, for the squeeze cast specimens with $100 \mathrm{MPa}$ pressure, the increase in the (UTS) was about $44.5 \%$. Also, the increase in the $\left(Y S_{0.2}\right)$ is about $38.3 \%$. The variation of the elongation with the applied pressure exhibits the same tendency regardless the specimen condition. It is about $70 \%$ in the squeeze pressure range of $100 \mathrm{MPa}$. Higher tensile properties of specimens squeeze casted under $100 \mathrm{MPa}$ applied pressure can be due to the modification of eutectic silicon and the refinement of $\alpha$-primay particles. After that, the applied pressure of more than $100 \mathrm{MPa}$ up to $150 \mathrm{MPa}$ decreases the tensile properties of the investigated alloy. The coarsening of dendrite size induces the degradation on the tensile properties. This is emphasized when the microstructure characteristics of specimens are produced under different applied pressures shown in Fig. 5 are compared. Therefore, tensile properties are strongly related to the microstructure, and when there is a refinement of the microstructure tensile properties are improved. 


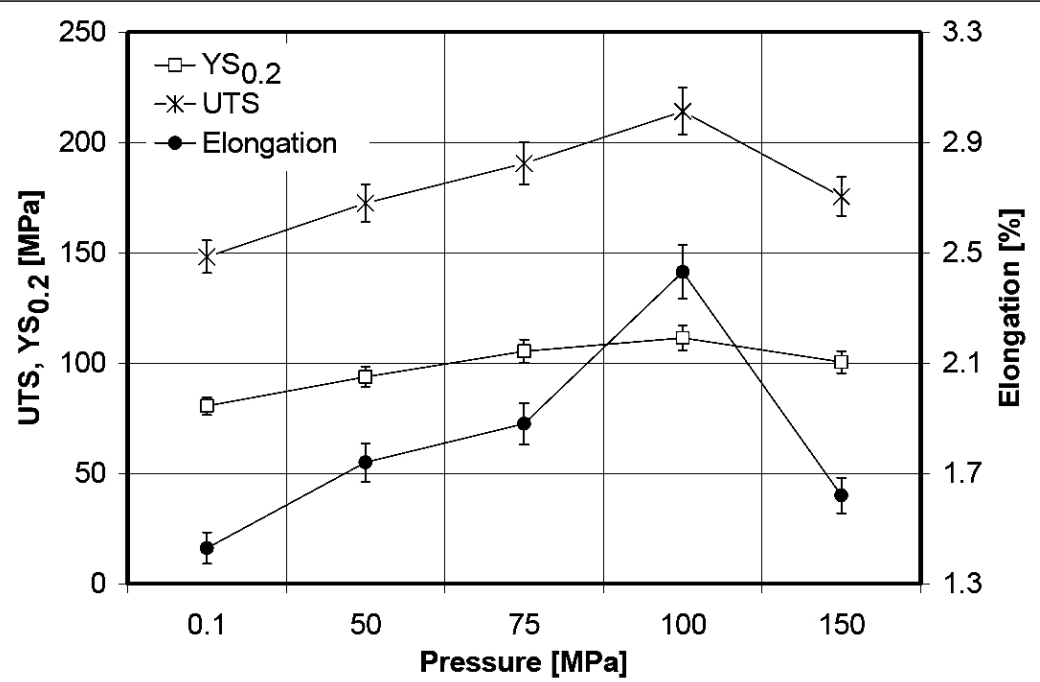

Fig. 5. Effect of pressure on UTS, YS 0.2 , and the elongation (\%) of alloy.

2.3. Effect of Pressure on Hardness. In order to confirm the tensile behavior with increasing applied pressures, the hardness of the cast samples is measured in the centre and at the edge. Figure 6 depicts the effect of pressure levels on the Vickers hardness of all cast specimens. A similar value is measured at the edge of the specimens for all the applied pressures, while a significant difference is observed only toward the center of the specimens.

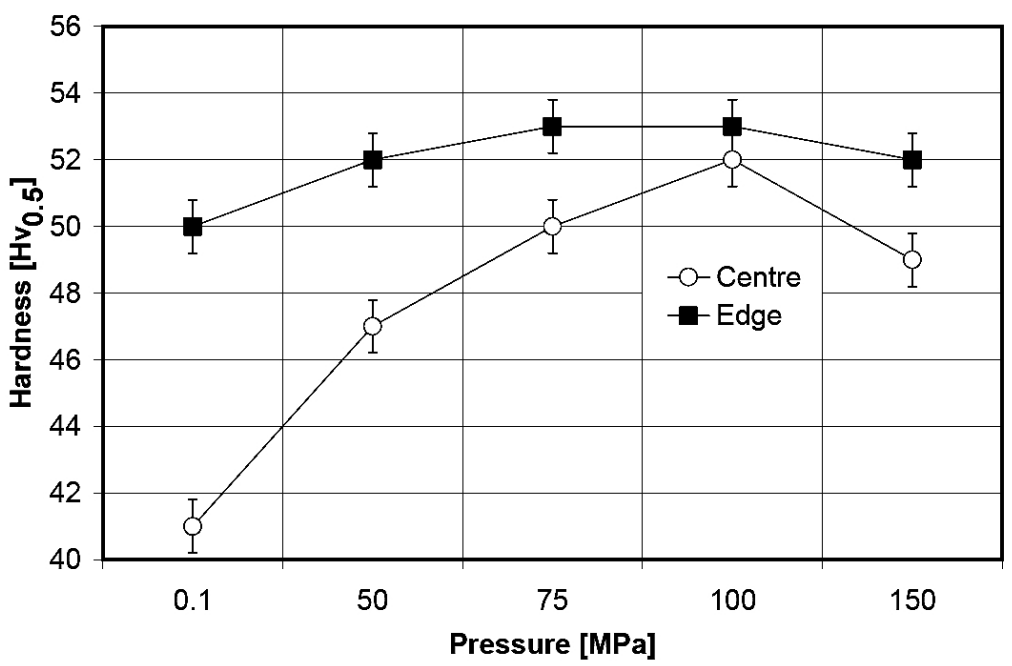

Fig. 6. Effect of pressure on the hardness of squeeze cast and gravity die cast specimens in the centre and at the edge.

In the specimen centre, the Vickers hardness increases steadily from 41 to 52 $H v_{0.5}$ when the applied pressure of squeeze casting changes from 0.1 to $100 \mathrm{MPa}$. In the edge, the hardness increases slightly from 50 to $53 H v_{0.5}$ when the applied pressure increases from 0.1 to $75 \mathrm{MPa}$, and then stabilizes until $100 \mathrm{MPa}$ applied pressure. This is due to the increase of cooling rate which is caused by improving 
contact between the metal and the die cast surface which not only results in refinement of the microstructure of specimens but also in the modification of eutectic silicon particles. The increase of hardness with applied pressure shows a good synchronized effect with increasing of tensile properties. Beyond $100 \mathrm{MPa}$ and up to $150 \mathrm{MPa}$ pressure, the Vickers hardness decreases significantly in the middle zone of sample. This could be due to the shear of fine silicon particles during severe deformation and hence the material loses its hardening mechanisms.

2.4. Fractographic Analysis. To better understand the failure mechanism of the castings under various squeezing pressures, the fracture surface of each specimen is examined with a scanning electronic microscope. Some of the SEM pictures are selectively presented in the current paper. The tensile fracture surface of the gravity die cast alloy as shown in Fig. 7 is brittle in nature. It is evident that an internal discontinuity due to the presence of porosity and a clustering of the shrinkage cavities (in the centre of Fig. 7a) serves as the initiation point of cracks in the gravity die cast specimens. The failure of the gravity die cast specimens is caused by a combined brittle fracture mechanism of void coalescence and intergranular fracture during tensile deformation (Fig. 7b). The growth and the coalescence of the cracks result in the final fracture. Figure 3a shows that the Al-rich dendritic matrix ( $\alpha$-Al phase) is coarse, which results in a bad ductility.
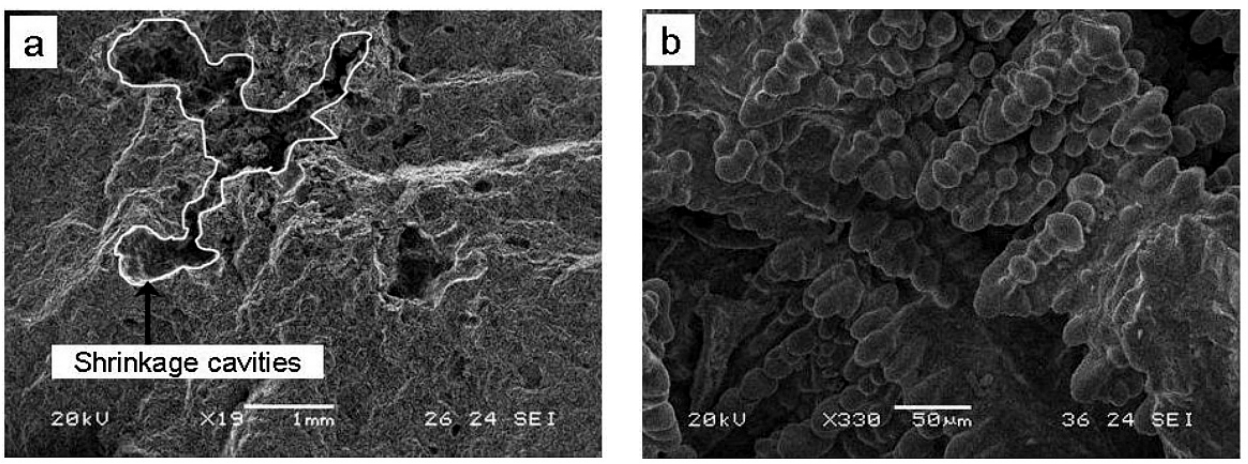

Fig. 7. Tensile fractographs (SEM) of gravity die cast specimen: (a) low magnification; (b) high magnification.

The tensile fracture surfaces of the squeeze cast specimens are shown in Fig. 8. All the specimens are fractured in a ductile and brittle manner consisting of well-developed dimples over the entire surface. The alloys failed in a mixed-mode fracture comprising of intergranular fractures, quasi-cleavage planes, and transgranular shears. Figure 8a shows the fracture surface of the squeeze cast specimen under $50 \mathrm{MPa}$. The irregular plate shapes of the quasi-cleavage are clearly apparent on the fracture surface. Moreover, the quasi-cleavages occupy a large area with a small number of dimples, indicating that the fracture characteristics exhibit mostly brittle behaviour. When the pressure reaches $75 \mathrm{MPa}$, the area of the quasicleavages is decreased, and the number of dimples is increased as seen in Fig. 8b. Hence, alloy ductility is increased as well (see Fig. 5). When the pressure reaches $100 \mathrm{MPa}$, the quasi-cleavages mostly disappear, the number of dimples is largely increased, and the pockets left by the small grains that are pulled out can be clearly observed (see Fig. 8c). The reasons for this may be due to the grain refinement and 

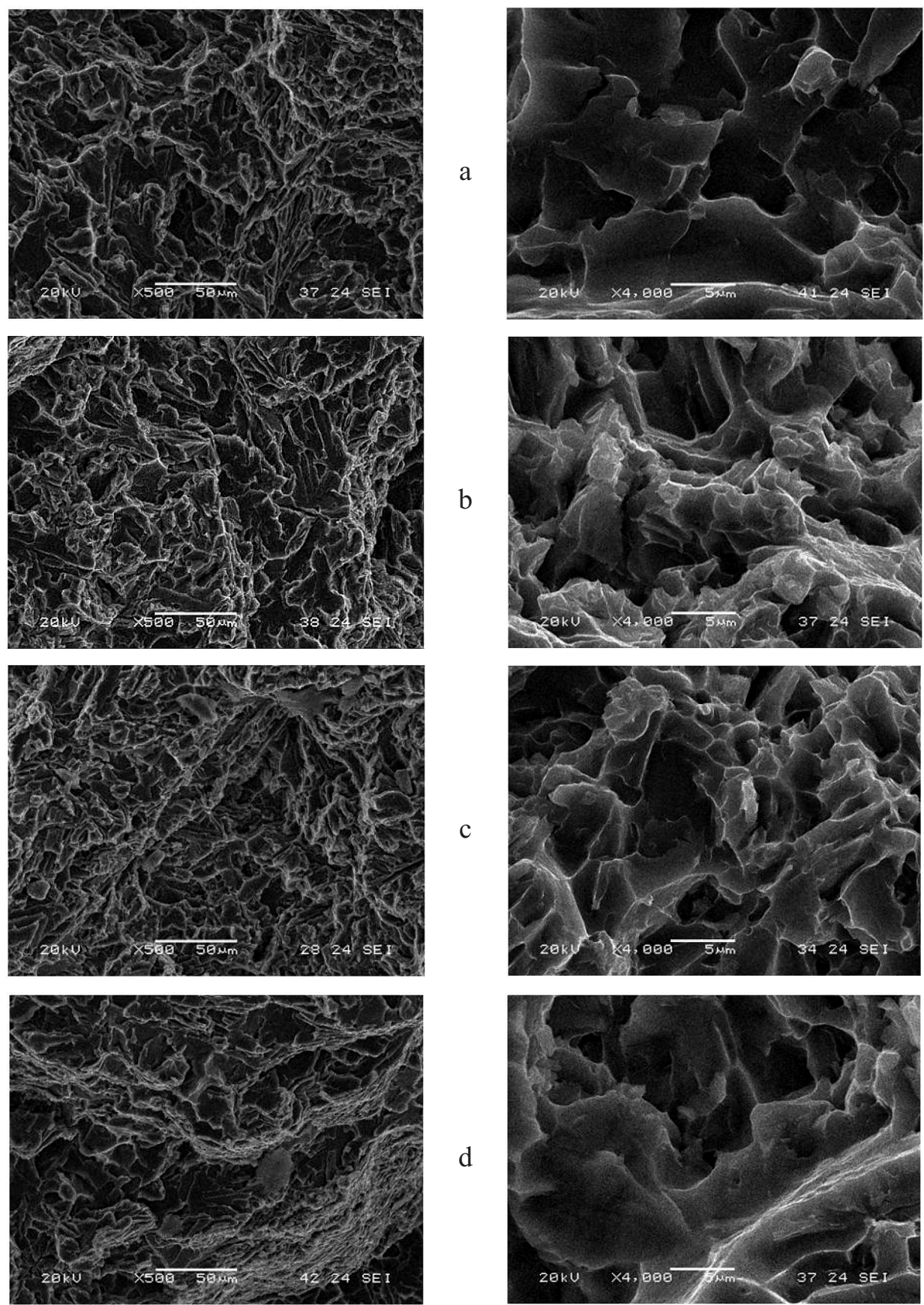

Fig. 8. Tensile fractographs (SEM) of squeeze cast specimens: (a) $50 \mathrm{MPa}$; (b) $75 \mathrm{MPa}$; (c) $100 \mathrm{MPa}$; (d) $150 \mathrm{MPa}$.

the work hardening, which resulted in the excellent yield strength (see Fig. 5) and hardness (see Fig. 6) of the alloy. When the pressure is increased to $150 \mathrm{MPa}$ the area of the quasi-cleavages are increased, and the number of dimples are decreased (see Fig. 7d), the growth of eutectic silicon is started, and the dendrites become coarse as shown in Fig. 4e and result in the decrease of the mechanical properties. 
Conclusions. The effects of the pressure on the microstructure and mechanical properties of the squeeze cast $\mathrm{Al}-13 \% \mathrm{Si}$ alloy which have a good castability are optimized in this work. The application of pressure has a significant effect on the morphology of the phases in squeeze cast $\mathrm{Al}-13 \% \mathrm{Si}$ alloy. When the applied pressure is increased from 0.1 up to $100 \mathrm{MPa}$ the cooling rate increases, which generates the reduction of the dendrites and the DAS. Also, increasing the applied pressure improves tensile properties and hardness. The microstructure refinement ameliorates the strength and the elongation values. The fracture mode is more ductile. There is almost a good agreement between microstructural observations and tensile test results, where the effect of grain refinement is more considerable. When the applied pressure in squeeze casting is increased up to $150 \mathrm{MPa}$, the DAS is increased, the tensile properties and the hardness of the investigated alloy is decreased. This is due to the severe plastic deformation in the presence of elevated temperature which causes the coarsening of dendrites size and the shear of fine silicon particles.

\section{Резиме}

Для лиття під тиском характерно прикладення тиску до заготовки при її твердінні, в результаті чого активізуються різні физичні процеси, що впливають на металургійні властивості литих сплавів. Експериментальне дослідження свідчить про вплив рівня тиску на мікроструктуру і механічні характеристики сплаву Al-13\%Si. Показано, що тиск при литті в інтервалі 0,1...100 МПа призводить до зменшення зерен, покращанню міцнісних властивостей і підвищенню твердості по Віккерсу в центральній частині зразка. При дії тиску 100...150 МПа мають місце високі попередні деформації за високої температури лиття і збільшення зерен. У результаті цього погіршуються міцнісні властивості і зменшується твердість. Аналіз мікрофотографій на електронному мікроскопі показує, що при дії тиску до 100 МПа механізм руйнування $\epsilon$ більш в’язким, ніж при підвищеному тиску. Це дозволяє оптимізувати рівень тиску з метою запобігання погіршення властивостей і ліквації матеріалу в процесі лиття під тиском.

1. P. Schmidt, J. Bast, M. Aitsuradze, and L. Arnberg, "Hollow castings produced by interrupted low pressure die casting," Int. J. Cast. Met. Res., 23, 1-6 (2010).

2. Kh. A. Ragab, A. M. Samuel, A. M. A. Al-Ahmari, et al., "Influence of fluidized sand bed heat treatment on the performance of AlSi cast alloys," Mater. Des., 32, 1177-1193 (2011).

3. C. M. Cepeda-Jiménez, J. M. Garcia-Infanta, A. P. Zhilyaev, et al., "Influence of the thermal treatment on the deformation-induced precipitation of a hypoeutectic Al-7 wt $\%$ Si casting alloy deformed by high-pressure torsion," J. Alloys Compd., 509, Issue 3, 636-643 (2011).

4. Y. Zedana, F. H. Samuela, A. M. Samuela, and H. W. Doty, "Effects of Fe intermetallics on the machinability of heat-treated Al-(7-11)\% Si alloys," J. Mater. Process. Technol., 210, Issue 2, 245-257 (2010). 
5. S. Nafisi and R. Ghomashchi, "Boron-based refiners: Advantages in semisolid-metal casting of Al-Si alloys," Mater. Sci. Eng. A, 452-453, 437-444 (2007).

6. N. A. Belov, D. G. Eskin, and N. N. Avxentieva, "Constituent phase diagrams of the $\mathrm{Al}-\mathrm{Cu}-\mathrm{Fe}-\mathrm{Mg}-\mathrm{Ni}-\mathrm{Si}$ system and their application to the analysis of aluminium piston alloys," Acta Mater., 53, 4709-4722 (2005).

7. R. Ashiri, B. Niroumand, F. Karimzadeh, et al., "Effect of casting process on microstructure and tribological behavior of LM13 alloy," J. Alloys Compd., 475, Issue 1-2, 321-327 (2009).

8. Rodrigo González, Dora I. Martinez, J. Alejandro González, et al., "Experimental investigation for fatigue strength of a cast aluminium alloy," Int. J. Fatigue, 33, Issue 2, 273-278 (2011).

9. Choong Do Lee, "Variability in the tensile properties of squeeze-cast Al-SiCu-Mg alloy," Mater. Sci. Eng. A, 488, 296-302 (2008).

10. Choong Do Lee, "Effect of damage evolution of Si particles on the variability of the tensile ductility of squeeze-cast $\mathrm{Al}-10 \% \mathrm{Si}-2 \% \mathrm{Cu}-0.4 \% \mathrm{Mg}$ alloy," Ibid, 527, 3144-3150 (2010).

11. X. Meng-Burany, T. A. Perry, A. K. Sachdev, and A. T. Alpas, "Subsurface sliding wear damage characterization in Al-Si alloys using focused ion beam and cross-sectional TEM techniques," Wear, 270, 152-162 (2011).

12. S. W. Kim, D. Y. Kim, W. G. Kim, and K. D. Woo, "The study on characteristics of heat treatment of the direct squeeze cast 7075 wrought Al alloy," Mater. Sci. Eng. A, 304-306, 721-726 (2001).

13. S. W. Youn, C. G. Kang, and P. K. Seo, "Thermal fluid/solidification analysis of automobile part by horizontal squeeze casting process and experimental evaluation," J. Mater. Process. Technol., 146, 294-302 (2004).

14. Crystopher Cardoso De Brito, Fabricio Dias Magalhães, André Luiz de Morais Costa, and Cláudio Alves Siqueira, "Microstructural analysis and tensile properties of squeeze cast Al-7\%Mg alloy," Mater. Sci. Forum, 643, 119-123 (2010).

15. Ming Zhou, Henry Hu, Naiyi Li, and Jason Lo, "Microstructure and tensile properties of squeeze cast magnesium alloy AM50," J. Mater. Eng. Perform., 14, No. 4, 539-545 (2005).

16. M. T. Abou El-khair, "Microstructure characterization and tensile properties of squeeze-cast AlSiMg alloys," Mater. Lett., 59, 894-900 (2005).

17. Yanfei Bai and Haidong Zhao, "Tensile properties and fracture behavior of partial squeeze added slow shot die-cast A356 aluminum alloy," Mater. Des., 31, Issue 9, 4237-4243 (2010).

18. S. Murali and M. S. Yong, "Liquid forging of thin Al-Si structures," J. Mater. Process. Technol., 210, 1276-1281 (2010).

19. A. Maleki, B. Niroumand, and A. Shafyei, "Effects of squeeze casting parameters on density, macrostructure and hardness of LM13 alloy," Mater. Sci. Eng. A, 428, Issue 1-2, 135-140 (2006). 
20. A. Maleki, A. Shafyei, and B. Niroumand, "Effects of squeeze casting parameters on the microstructure of LM13 alloy," J. Mater. Process. Technol., 209, Issue 8, 3790-3797 (2009).

21. C. H. Fan, Z. H. Chen, W. Q. He, et al., "Effects of the casting temperature on microstructure and mechanical properties of the squeeze-cast $\mathrm{Al}-\mathrm{Zn}-\mathrm{Mg}-\mathrm{Cu}$ alloy," J. Alloys Compd., 504, Issue 2, L42-L45 (2010).

22. ASM Handbook, Vol. 9: Metallography and Microstructures, Materials Park, $\mathrm{OH}$ (1986), pp. 334-435.

23. A. Boschetto, G. Costanza, F. Quadrini, and M. E. Tata, "Cooling rate inference in aluminum alloy squeeze casting," Mater. Lett., 61, Issues 14-15, 2969-2972 (2007).

24. Ming Zhang, Wei-wen Zhang, Hai-dong Zhao, et al., "Effect of pressure on microstructures and mechanical properties of Al-Cu-based alloy prepared by squeeze casting," Trans. Nonferrous Met. Soc. China, 17, No. 3, 496-501 (2007).

25. M. R. Ghomashchi and A. Vikhrov, Squeeze casting: an overview, J. Mater. Process. Technol., 101, Issues 1-3, 1-9 (2000). 